\title{
LEGAL AND POLITICAL SOURCES OF THE TREATY ESTABLISHING A CONSTITUTION FOR EUROPE
}

\author{
Jo Shaw, Professor and Jean Monnet Chair of European Law, \\ University of Manchester, Senior Research Fellow at the Federal \\ Trust for Education and Research, London ${ }^{1}$

\section{INTRODUCTION}

The focus of this paper is the draft Treaty establishing a Constitution for Europe, prepared by the Convention on the Future of Europe between the end of February 2002 and the middle of July 2003, ${ }^{2}$ and the subsequent work done by the Intergovernmental Conference (IGC) convened in October 2003

1 This paper builds upon my previous work on the development of a European Constitution, especially a paper published as 'What's in a Convention', in J. Shaw, P. Magnette, L. Hoffmann and A. Vergés Bausili, The Convention on the Future of the Union: Working Towards an EU Constitution, London: Federal Trust/Kogan Page, (2003). I would like to acknowledge the comments of a number of people, including some quite 'close' to the Convention's core, who should in all conscience remain anonymous, but who saved me from a number of misunderstandings of the workings of the Convention, but I remain, of course, responsible for any errors contained herein. I am grateful to the many people who made comments on various papers which I have drafted or presented on the Convention and the Constitutional Treaty, and for the assistance of the members of the EU Constitution team at the Federal Trust.

2 OJ 2003 C169/01. For commentary on the draft Constitutional Treaty see: I. Pernice and M.P. Maduro (eds), A Constitution for the European Union: First Comments on the 2003-Draft of the European Convention, 2004; A. Arnull, 'Member States of the European Union and Giscard's Blueprint for its Future', (2004) 27 Fordham International Law Journal 503; J. Temple Lang, 'The main issues after the Convention on the Constitutional Treaty for Europe', (2004) 27 Fordham International Law Journal 544; P. Birkinshaw, 'A Constitution for the European Union? - A Letter from Home', (2004) 10 European Public Law 57; P. Craig, 'Competence: clarity, conferral, containment and consideration', (2004) 29 European Law Review 323; A. Dashwood, 'The Draft EU Constitution - First Impressions', (2002-2003) 5 Cambridge Yearbook of European Legal Studies 419; M. Dougan, 'The Convention's draft Constitutional Treaty: bringing Europe closer to its lawyers?', (2003) 28 European Law Review 763; J. Dutheil de la Rochère, 'The EU and the Individual: Fundamental Rights in the Draft Constitutional Treaty', (2004) 41 Common Market Law Review 345; J. Klabbers and P. Leino, 'Death by Constitution? The Treaty establishing a Constitution for Europe', (2003) 4 German Law Journal 1293 <www.germanlawjournal.com>; J. Kokott and A. Ruth, 'The European Convention and Its Draft Treaty Establishing a Constitution for Europe: Appropriate Answers to the Laeken Questions?', (2003) 40 Common Market Law Review 1315; J. Ziller, La nouvelle Constitution europeénne, 2004; P. Craig, 'What Constitution does Europe need? The House that Giscard built: Constitutional Rooms with a View,' Federal Trust Online Constitutional Essay, 26/2003 <www.fedtrust.co.uk/eu_constitution>; M. Dougan, 'The Convention's Draft Constitutional Treaty: A 'Tidying-Up Exercise' That Needs Some TidyingUp Of Its Own', Federal Trust Online Constitutional Essay, 27/2003 <www.fedtrust.co.uk/eu_constitution>. 
to prepare a final version of this Treaty. This work culminated in political agreement amongst the Heads of State and Government of the Member States at the meeting of the European Council in Brussels in June 2004 on a Treaty, due for signature on 29 October 2004 in Rome. ${ }^{3}$ This text will in turn be placed before the Member States for ratification in accordance with their respective constitutional requirements. ${ }^{4}$ If the so-called Constitutional Treaty $(\mathrm{CT})^{5}$ is ratified by all the Member States and enters into force, it will replace the existing EU and EC Treaties, and associated protocols and annexes, as well as giving legal force to the declaratory Charter of Fundamental Rights, agreed in $2000 .^{6}$

The broad objective is to place these various texts in a wider constitutional context. That is to say, the paper works from the premise that the EU has been engaged for some time, in particular but not solely through the Convention and IGC processes, in a constitution-building project. This constitution-building process can itself be broken down into a number of interdependent but partially separate elements. The particular focus of this paper is the work undertaken by the Convention in elaborating the initial draft, which the IGC then worked on to produce the final text. The Convention was a novel element superimposed onto the existing EU Treaty amendment procedure as a result of the Laeken Declaration of the European Council in December 2001. ${ }^{7}$ The text produced by the Convention was in turn essentially informal in nature and has been altered in many significant respects by the ensuing IGC, even though strenuous efforts were made within the Convention context by leading figures such as the President Valéry Giscard d'Estaing to ensure that the product of the Convention would be something which was already acceptable to the Member States. This has

3 See the final agreed (and renumbered) text: CIG 87/04, 6 August 2004. Until this final version, each separate Part (I-IV) of the Constitutional Treaty had been numbered from 1. This gave rise to numbering such as Article I-1; Article II-1; Article III-1, etc. In the final version, a small number of provisions were reassigned (e.g. the provision on symbols, flag and motto, originally included in Part IV by the Convention was moved to Part I). The whole Constitutional Treaty is now numbered Articles 1-448, but the location of different articles in different Parts of the Treaty is designated by the prefix of a roman numeral. Thus Article II-1, in the old version, is now Article II-61. The impact of this is greatest upon Part II, which is the Charter of Fundamental Rights, of which some articles were already quite well known. It will be quite confusing initially that Articles 51-54 of the Charterthe so-called horizontal clauses concerned with the effects of the Charter - are being renumbered Articles II-111-114 CT.

4 Art 48 of the Treaty on European Union.

5 For initial comment on the final text of the Constitutional Treaty, see J. Emmanoulidis, Historically Unique, Unfinished in Detail - An Evaluation of the Constitution, Bertelsmann Foundation Paper on EU Reform, 2004/03 <www.eureform.de>; Centre for European Reform, The CER Guide to the EU's Constitutional Treaty, Policy Brief, July 2004 <www.cer.org.uk>. D. Phinnemore, The Treaty Establishing a Constitution for Europe: An Overview, RIIA EP BN 0401 <www.chathamhouse.org.uk>.

6 OJ 2000 C364/01.

7 Annexes to the Presidency conclusions - Laeken, 14 and 15 December 2001, SN 300/01 ADD 1, ANNEX I, Laeken Declaration on the Future of the European Union 〈http://european-convention.eu.int/pdf/LKNEN.pdf>. 
been described as 'bargaining in the shadow of the IGC'. ${ }^{8}$ However, as regards the specific issues of substance discussed in this paper, the IGC made no major changes to the materials prepared by the Convention.

The debate about a putative European Constitution did not emerge suddenly during the Convention. On the contrary, it has been widely argued, especially by legal academics and those working within the European Union institutions, that the EU has long had a type of 'unwritten' and composite constitution, based on the principles of the EU legal order developed by the Court of Justice, and supplemented by key aspects of the Treaty framework. This has often been described as the Court of Justice's 'constitutionalisation' of the Treaties, and a particular focus is placed upon the principles of supremacy and direct effect, the development of concepts of competence, and the articulation of a doctrine of fundamental rights. The Court of Justice did announce in the 1986 case of Les Verts ${ }^{9}$ that the EC Treaty can be characterised as the Community's 'constitutional charter' ${ }^{10}$

Thus the Convention did not operate against the background of a constitutional tabula rasa in relation to either the process of constitutionbuilding or the substantive constitutional 'choices' which it made when it prepared the different parts of its draft of the Constitutional Treaty. But constitution-building in the EU since the inception of the first treaties has always comprised a set of complex interactions and tensions between the Treaty texts and other formal and even informal institutional documents (e.g. the Charter of Fundamental Rights, 2000), on the one hand, and their interpretation by key actors, notably the Court of Justice, but also the national courts, and the other non-judicial EU institutions, on the other. This has been characterised as a distinction between the 'formal' and 'real' constitutions of the EU, ${ }^{11}$ and as a form of 'low intensity' constitutionalism. ${ }^{12}$

This complex patchwork of constitutional norms and practices maps onto both the procedural and substantive dimensions of the Convention's work. The core of the argument is that the acquis is a key political and legal source

8 See P. Magnette and K. Nicolaïdes, 'The European Convention: Bargaining in the shadow of rhetoric', (2004) 27 West European Politics 381.

9 Case 294/86 Parti Ecologiste 'Les Verts' v Parliament [1986] ECR 1339. It repeated the point in Opinion 1/91 Draft Agreement on a European Economic Area (EEA) [1991] ECR I-6079. It is sometimes remarked upon that the Court has not repeated this point since the European Union famously ran aground on the sands of the legitimacy question, in the wake of the Maastricht ratification debacle.

10 Some commentators caution that since the inception of the EU - i.e. the entry into force of the Treaty of Maastricht in 1993 - the Court of Justice has avoided 'constitutional' language, and has certainly not characterised the overall 'pillar framework' introduced by the Treaty on European Union as the EU's constitutional charter, as it did for the EC Treaty in Les Verts.

11 G. de Búrca, 'The Institutional Development of the EU: A Constitutional Analysis', in P. Craig and G. de Búrca (eds.), The Evolution of EU Law, 1999.

12 M.P. Maduro, 'How Constitutional Can the European Union Be? Reconciling Intergovernmentalism with Constitutionalism in European Constitutionalism', Paper presented at Altneuland: The Constitution of Europe in an American Perspective, NYU-Princeton Conference, April $2004<\mathrm{http}: / / \mathrm{www}$.jeanmonnet program.org/>. 
of the draft Constitutional Treaty drawn up by the Convention. ${ }^{13}$ For example, in relation to procedural questions such as 'how, when and where does constitutional development of the EU take place?', it is clear that constitutional development occurs in a number of overlapping forums, such as IGCs, national ratification processes for new treaties (which have included some key national constitutional court judgments ${ }^{14}$ ), and subsequent interpretations and applications of the treaties by the Court of Justice and other institutional actors. The question which this paper considers is how the Convention has added to the process of the development of the acquis through its working methods and through the management of the process by key actors such as President Giscard d'Estaing.

In relation to the substantive content of the Constitutional Treaty, this paper looks at the use of the composite constitutional acquis of the EU in the context of the development of the text of a Constitutional Treaty. It examines the ways in which the Convention's work on matters of substance was structured by the complex heritage of the Union's constitutional acquis. The paper shows that the Convention has begun to force political actors at the national and European levels to confront more directly than ever before some key questions about what European constitutionalism already is, especially in legal terms. In other words, there are key political questions about the management and deployment of the legal sources of EU constitutionalism as it exists under the current dispensation. Political actors must face questions about the extent to which they might wish the realities of European constitutionalism (such as the principle of the supremacy of EU law) to remain hidden from public view in the future as in many respects they have done hitherto. Can the delicate balance of the national and the supranational dimensions of European integration (not to mention the subnational and international inputs which it experiences) survive the sometimes harsh scrutiny to which it was subjected within the confines of the Convention process?

To set the scene for this discussion, it is important to reiterate some basic premises about the evolution of the EU constitutional framework from the inception of the first treaties until the present time. Even though it was not until the Laeken Declaration in December 2001 that the European Council first formally acknowledged the possibility of a 'Constitution' for the European Union, the idea of analysing European integration in constitutionalist terms has been well-established for decades. While the practice has been particularly common amongst lawyers, it has also extended to both students and practitioners of politics. ${ }^{15}$ At the same time, however,

13 On the role of the acquis communautaire in relation to the governance of the EU see A. Wiener, 'The Embedded Acquis Communautaire: Transmission Belt and Prism of New Governance', (1998) 4 European Law Journal 294.

14 Most famously the German Federal Constitutional Court on the Treaty of Maastricht and the German constitution: Brunner [1994] 1 CMLR 57.

15 E.g. B. Kohler-Koch, 'A Constitution for Europe?, Working Paper of the Mannheim Centre for European Social Research, 8/1999; C. Church and D. Phinnemore, The Penguin Guide to the European Treaties, 2002 at p.15; W. Wessels, 'Der Verfassungsvertrag in im Integrationstrend: Zusammenschau der zentralen Ergebnisse', (2003) 26 Integration 284 ; J. Fischer, From Confederation 
the constitutional question remains highly contested in relation to the innumerable sub-questions which it encapsulates, including the very purpose and scope of a constitution for an entity such as the EU which is not formally a state in the Westphalian sense, albeit that it is a polity which wields many instruments and undertakes many tasks of a state-like nature. On the contrary, it operates in some sort of ambiguous liminal space between states and international organisations according to the conventional definitions of national and international law, and it is widely regarded as deserving of analysis above all as a sui generis entity which cannot easily be assimilated to other known forms of political organisation. Above all, however, the very ethic of European constitutionalism remains contested. ${ }^{16}$

It is equally important to develop principled reference points for viewing both the evolution of the Convention process and the substantive outcomes which the Convention adopts. Elsewhere I have argued for the importance of a critical assessment of the Convention process, in the light of principles of responsible and inclusive constitutionalism. ${ }^{17}$ This paper has a separate but related objective to link the tensions which frame the procedural dimension of the Convention to some of the key elements of its substantive debate. With that objective in mind, the paper looks explicitly at the constitutional acquis as the backdrop to the constitution-building process, as well as contributing to reflection upon the novelty and sui generis nature of the Convention process. That paradox of the rootedness of the Convention's discussions in the constitutional acquis at the same time as it proposes sometimes innovative solutions to apparently intractable problems will remain, in my view, one of the most enduring features of the Convention experience.

What is clear, therefore, is that constitution-building is both a legal and a political process. This lies behind the preoccupation in this paper with identifying and analysing the legal and political sources of the draft European Constitutional Treaty.

\section{The Procedural Dimension of Convention-Watching: The 'Building' of the Convention 'acquis'}

The Convention on the Future of Europe comprised a body of 105 members, plus the same number of alternates, including representatives of the national governments, national parliaments, the European Parliament, and the European Commission, plus sundry observers. ${ }^{18}$ Representatives came from both the fifteen Member States at the time, and the thirteen candidate countries at the time (the ten states which acceded in May 2004, plus Bulgaria, Romania and Turkey). It was led by a three person Presidency, comprising Giscard d'Estaing, plus two Vice-Presidents (former Italian

to Federation - Thoughts on the Finality of European Integration, Speech given at the Humboldt University, Berlin, Germany, 12 May 2000.

16 J. Shaw, 'Postnational constitutionalism in the European Union' (1999) 6 Journal of European Public Policy 579.

17 J. Shaw, 'Process, Responsibility and Inclusion in EU Constitutionalism', (2003) 9 European Law Journal 45.

18 For an outline presentation of the Convention, see B. Crum, 'Politics and Power in the European Convention', (2004) 24 Politics 1. 
Prime Minister Giuliano Amato and former Belgian Prime Minister Jean-Luc Dehaene), plus a so-called Praesidium, comprising representatives of each of the component groups of the Convention, which was charged with taking a leading role in drafting. Secretariat services were ensured by a group led by Lord Kerr of Kinlochard, a former British diplomat (then Sir John Kerr), with members seconded from both the EU institutions, and some of the national civil services. At the very beginning, it was not wholly clear from the so-called Laeken mandate what the role of the Convention was going to be. This was somewhat ambivalent about what the Convention should produce. Should it be merely a statement of the differences between the negotiating parties, as occurred with the Reflection Group which preceded the 1996-97 IGC and the Treaty of Amsterdam? Or should it be a group or or even a single text responding to the needs of simplification and legitimation articulated above all in the Laeken Declaration. Most agree that the Laeken Declaration was sufficiently vague to produce a blank canvas on which to paint a number of competing visions about both the purpose of the Convention and the nature of the European integration process. ${ }^{19}$

President Giscard d'Estaing's first speech to the opening session of the Convention on 28 February 2002 asserted very clearly his belief in the constitutive power and capacity of the Convention. It seems very likely that he did not at the time anticipate that the Convention would conclude as it did - with a 'full' draft Constitutional Treaty for the European Union - but that did not stop him articulating ideas in his first speech in 'constitutional' terms. Mentioning the word 'constitution' three times, he then concluded with a powerful attempt to pre-empt much debate by declaring the aim of the Convention thus: ${ }^{20}$

"The Laeken Declaration leaves the Convention free to choose between submitting options or making a single recommendation. It would be contrary to the logic of our approach to choose now. However, there is no doubt that, in the eyes of the public, our recommendation would carry considerable weight and authority if we could manage to achieve broad consensus on a single proposal which we could all present. If we were to reach consensus on this point, we would thus open the way towards a Constitution for Europe. In order to avoid any disagreement over semantics, let us agree now to call it: a "constitutional treaty for Europe"." (emphasis in the original)

This is a powerful presentation of the historical opportunity which Giscard saw the Convention as presenting - an opportunity which he might have seen in a certain sense as being for himself as an individual, but which he effectively portrayed to the new Convention as a collective opportunity. This sense of opportunity in turn spoke eloquently to the federalist majority amongst the Convention members. Thus the constitutionalist endeavour

19 P. Craig, 'Constitutional Process and Reform in the EU: Nice, Laeken, the Convention and the IGC', FCE 3/04 < www.whi-berlin.de>.

20 V. Giscard d'Estaing, 'Introductory Speech to the Convention on the Future of Europe', SN 1565/02, Brussels, 26 February 2002 (delivered 28 February 2002), at p.11. 
became Giscard's main 'gift' to the Convention, which meant that despite subsequent tensions, his leadership still retained a substantial element of goodwill amongst the ordinary Convention members. It was from this point on, however, that the Convention engaged in a form of constitution-building. This section examines the procedural dimension of this constitutional construction in terms of its political and legal sources.

Commentaries on the Convention have frequently pointed out that the Convention was clearly more open, more transparent and more inclusive than an IGC, that it 'decided' by 'consensus' and did not incorporate a set of formal veto arrangements, and that it involved a wider range of elites, giving an institutionalised voice to the European Parliament and to national parliaments in the process. ${ }^{21}$ Procedural perspectives on the Convention have focused on the ways in which the Convention has supplemented the existing constitutionalisation processes of the European Union, for example, by adding a 'pre-contractual' phase to the process whereby Member States presently agree upon changes to the international treaties which remain the formal construct of European integration ${ }^{22}$ and by introducing the notion of consensus amongst elites as the basis for 'agreeing' a new constitutional settlement. At the very least, the constitutional dialogues which shape the EU have been immeasurably enriched by the complex constellations of interest intermediation which the Convention comprised in its plenary debates, working groups, and discussion circles, and in its draft texts and amendments. Furthermore, in more or less open ways, the Convention and its members remained in constant dialogue with external interests, such as national parliaments, other European institutions, civil society and even academia. The Convention experience has offered as a minimum a suggestion of the promise of deliberation, and perhaps a great deal more than that. ${ }^{23}$

In fact, formal constitution-building in the European Union has long been a complex, multi-staged process, already involving an ever increasing range of actors. $^{24}$ While the first significant set of amendments to the EEC Treaty the Single European Act of 1986 - might have occurred away from the glare of all but the most Europe-focussed publicity, subsequent cases of Treaty amendment, although often not front-page affairs, have attracted much more substantial media coverage, not least because of the referendum affairs in

21 See generally C. Closa, 'The Convention method and the transformation of EU constitutional politics', in E.O. Eriksen, J.E. Fossum and A.J. Menéndez (eds.), Developing a Constitution for Europe, 2004; L. Hoffmann, 'The Convention on the Future of Europe: Thoughts on the Convention-Model', in J. Shaw, P. Magnette, L. Hoffmann and A. Verges, The Convention on the Future of Europe: Working towards an EU Constitution, 2003; L. Hoffmann and A. Vergés Bausili, 'The reform of Treaty revision procedures: the Convention on the Future of Europe', in T. Börzel and R. Cichowski (eds.), State of the European Union, Volume 6: Law, Politics and Society, 2003.

22 B. de Witte, 'The Closest Thing to a Constitutional Conversation in Europe: the Semi-Permanent Treaty Revision Process', in P. Beaumont, C. Lyons and N. Walker (eds), Convergence and Divergence in European Public Law, 2003, pp.3957.

23 P. Magnette, 'Deliberation or bargaining? Coping with constitutional conflicts in the Convention on the Future of Europe', in Eriksen et al, above n.21.

24 Closa, above n.21. 
Denmark (Maastricht), France (Maastricht) and Ireland (Nice). As things stand, the Convention has added a further pre-contractual stage to the process; the convening of a Convention does not - and cannot, at least until the rules of the game are themselves formally changed by Treaty amendment - formally pre-empt or replace the Intergovernmental Conference as the site within which formal commitments are made between the Member States. The latter remain the legal 'Masters of the Treaty', and are likely to do so for the foreseeable future.

On the other hand, so far as the Member States were required by the Convention to engage in the endeavour to find compromise and consensus positions on key questions about the missions, functions, values and operating procedures and practices of the European Union which have historically been fudged or swept to the sidelines as posing insoluble problems, they did so in a very different framework to that of an intergovernmental conference. It is significant that in some measure at least, the Convention constituted a shift from the exchange of concessions and compromises to the exchange of reasons amongst participants. ${ }^{25}$ To a certain extent, the Member States found themselves 'locked in' by their participation in the Convention process. In part, they reacted to that by seeking to make the Convention more like an IGC, as more and more states nominated foreign ministers or other cabinet rank ministers to be their representatives on the Convention as its work progressed. On the other hand, the change in the environment partially enabled the Convention - and the Member States in particular - to break away from certain taboos which have constrained state behaviour within IGCs when discussing historical blocking points such as institutional reform and the question of the future of the institutional system designed in the 1950s for a 'Community' of Six, rather than a twentyfirst century 'Union' of Twenty-Five+.

One clearly important innovation, for example, which created a very different feel to the Convention as compared to the IGC was the presence of national opposition parties through the medium of national parliamentary representatives and European parliamentary representatives, sitting in the same debating chamber and round the same negotiating table as national governmental representatives. This in some respects broke down the sense of the unitary 'national' interest as represented by national governments which had often stifled the development of intergovernmental negotiations and ensured that they have predictably remained bargaining rather than deliberation scenarios. Indeed, this change seemed to offer the promise of deliberation - if not yet quite the reality, or so the consensus of reports from professional Convention-watchers generally has seemed to indicate. ${ }^{26}$ In

25 See F. Deloche-Gaudez, 'Le Secretariat de la Convention Européenne: un acteur influent', (2004) Politique Européenne, no. 13, Spring 2004, 43 at p.44.

26 Attempts to capture more of this promise of deliberation are evident in mid-stream changes to how the Convention works introduced by the Praesidium, such as the innovation of more frequent plenary meetings, the reduction in speaking time, and the decision to allow spontaneous interventions through the raising of 'blue cards', all designed to reduce the tendency of plenary to be a sequence of 'soap-box' speeches: see 'Convention faces change of philosophy test', 27 February 2003 <www.euobserver.com>. See also generally P. Norman, The Accidental 
truth, over the years many competing stories will be written about how and why the Convention reached the conclusions that it did.

From the perspective of legal analysis, it is important to stick quite closely to the available documentation, in order to ground the discussion. One of the most important frameworks for 'knowing' about the Convention was its website. ${ }^{27}$ From the perspective of wider communication with publics, this website was wholly inadequate. Within a very few months of the Convention's inception, there was already an overwhelming body of written material on its website. This effectively precluded the casual visitor to the site from gaining anything more than a very superficial review of what the Convention was and did from the very brief and relatively uninformative introductory materials which the website provided. The website did not explain for the general user how and why the Convention was in fact working towards a new Constitutional Treaty, making reference briefly to some of the questions in the Laeken Declaration, but omitting any form of articulation of how the Convention agenda and approach shifted in its early months into the constitutional register. ${ }^{28}$ During the lifetime of the Convention, clicking on the heading 'Draft Constitutional Treaty' on the website merely brought up the highly impenetrable skeleton put forward by the Praesidium in October $2002,{ }^{29}$ the rafts of draft articles which followed after January 2003, and the multitudes of amendments put forward by Convention members. ${ }^{30}$ These were followed, as the texts were gradually put together, by successive Praesidium re-drafts, such that by the end of the hectic few final weeks it would only have been clear to a close observer of the events and of changes on the website exactly what was the final text of the four parts of the Constitutional Treaty 'approved' in Plenary on 13 June and 18 July 2003. ${ }^{31}$ That is the negative side of the Convention and its website, which was quickly turned into a tool which would be useful only to those staying very close to the Convention debate. The positive side of the website lies in that very same mass of material which is impenetrable to the casual visitor, but which can in fact reveal to those who have followed the process from the beginning much of the complexity and richness of the constitution-building process, and the different elements of which it is composed.

Constitution. The Story of the European Convention, 2003; A. Dauvergne, L'Europe en Otage? Histoire secrète de la Convention, 2004.

$27<\mathrm{http} / / /$ european-convention.eu.int/>.

28 Those with a more casual or occasional interest would have needed to turn to websites such as the Federal Trust EU Constitution Project <www.fedtrust.co.uk/eu_constitution> which observed the Convention from the outside.

29 CONV 369/02 of 28 October 2002.

30 See <http://european-convention.eu.int/amendemTrait.asp?lang=EN>

31 The most important documents were CONV 797/1/03 REV 1, Text of Part I and Part II of the Constitution, 12 June 2003, CONV 802/03, Draft Constitution. Volume II, 12 June 2003 and finally, after the July reconvening of the Convention, CONV 850/03, 18 July 2003. 
This process has involved the creation and deployment for developmental purposes of the Convention's own acquis, ${ }^{32}$ based on deliberations in working groups and plenary, the prefatory, summative and drafting work of the Secretariat including the preparation of working documents and questionnaires, reports, summaries of meetings and draft articles, and the discussions and resolutions of the Praesidium. Not all of these processes and outcomes were equally public. Notably the Praesidium always deliberated behind closed doors, and - notwithstanding objections ${ }^{33}$ - did not publish minutes of its meetings, at least not until after the conclusion of the Convention. ${ }^{34}$ Moreover, these 'minutes' were deliberately drafted in order not to be revelatory. It was obvious from the beginning of the Convention's work that notwithstanding their non-publication that they were in practice being 'circulated' by Praesidium members to their 'composants' (i.e. the groups they worked within, such as the group of MEPs, or national members of Parliament, or representatives of national governments) as well as to political family colleagues. The deliberately bland nature of the minutes as drafted was chosen in order to 'safeguard Praesidium decision-making capability', ${ }^{35}$ and indeed it was apparent that the European Ombudsman sympathised with this political imperative when the refusal to publish the minutes during the course of the Convention's work was referred to him in early 2003. ${ }^{36}$

Working Group meetings, furthermore, were generally not open to public observation, whereas plenary meetings were not only public and televised/webcast (and fully linguistically accessible because of simultaneous interpretation), but were also recorded verbatim in transcripts on the European Parliament website, initially in the original language of each statement, but ultimately to be made available in all official languages.

The analysis of Secretariat documentation - much of which was passed via the Praesidium for approval and adopted as Praesidium documentation, sometimes with, and sometimes without amendment - is perhaps the most illuminating exercise in excavating the emergence of the Convention's acquis. ${ }^{37}$ Theoretically, the Secretariat could have provided the bridge between the Convention and some of the most effective institutional players in the EU, namely the secretariats and legal services of the Council and the

32 A term used by Convention Vice-Chairman Jean-Luc Dehaene, as quoted in B. Crum, 'Towards Finality: A Preliminary Assessment of the Achievements of the European Convention', ARENA Working Paper WP 03/4 < www.arena.uio.no>.

33 Objections have come notably from Convention members in political factions which are not represented in the Praesidium, such as the Green/EFA working collaboration on the Convention and the GUE/NGL group. In May 2003 the Praesidium decided that after the conclusion of the Convention's work, its documents should be made publicly available via the website.

34 'Praesidium documents' at <http://european-convention.eu.int>.

35 Private communication from a senior official within the Secretariat.

36 Decision of the European Ombudsman on complaint 1795/2002/IJH as it relates to the European Convention at $\langle$ http://www.euro-ombudsman.eu.int $>$.

37 See generally on the Secretariat as an 'influential actor', Deloche-Gaudez, above n.25. Providing a methodology for the study of Secretariats, especially those within IGCs, see generally D. Beach, 'The unseen hand in treaty reform negotiations: the role and influence of the Council Secretariat', (2004) 11 Journal of European Public Policy 408. 
Commission, which have an unparalleled expertise in understanding the present state of EU law as well as a background as repeat players in IGCs over the years. This was certainly true so far as many of members of the Convention Secretariat were drawn from the services of the Council and the Commission, as well as that of the European Parliament and a number of national diplomatic services. In practice, the Convention Secretariat acted in large measure in isolation. Such an independent and autonomous Secretariat was not foreseen in the Laeken Declaration, but in practice the Council Secretariat wanted to keep itself rather separate, in view of the fact that it would later be providing secretarial services to the IGC. In addition, President Giscard d'Estaing wanted to reinforce the autonomy of the Convention and sought an autonomous Secretariat, with many handpicked members given his personal seal of approval. ${ }^{38}$ The Commission's interventions in the Convention's work were, as a general rule, hamstrung greatly by the lack of an effective political engagement on the part of the Commission with the Convention. This meant, for example, that neither the Commission Legal Service, nor any of the other expert teams working on the Convention, such as those assisting Commission President Prodi, or Convention members Commissioners Barnier and Vitorino were able to make the first move in presenting key proposals to the Convention. They were restricted to the reactive role of commentator, and this reflected back once again on the general political weakness of the Commission at the present time. It goes without saying that the public relations debacle of the presentation of the so-called Penelope project, intended to demonstrate the legal feasibility of the Commission's political project for the EU, ${ }^{39}$ greatly harmed the effectiveness of the Commission as an influential actor within the Convention.

The Convention Secretariat was certainly no mere 'administrator' of the Convention. It played an essential role in setting out the richness and variety of the EU's existing constitutional acquis by preparing and issuing documentation notes on issues such as the present system of competence distribution and allocation, the legal instruments of the EU, the nature of the open method of coordination, the state of play in external action and justice and home affairs, the role of national parliaments and the institutions of the $\mathrm{EU}$, and on the regional and local dimension of EU governance. While largely descriptive, these papers had the capacity also to shape debate because of their effective command of the current status quo. Allied to this, the Secretariat more directly shaped debate by preparing papers on questions such as the possibilities of simplification as envisaged by the Declaration on the Future of the Union and the Laeken Declaration. ${ }^{40}$ In that sense, the

38 Deloche-Gaudez, above n.25 at p.45 et seq.

39 European Commission, 'Feasibility Study: Contribution to a Preliminary Draft Constitution of the Europena Union', 4 December 2002 (presented on 5 December 2002), Working Document <http://europa.eu.int/futurum/docinstcomm_2002_ en.htm>.

40 See CONV 250/02 Simplification of the Treaties and Drawing up of a Constitutional Treaty, 10 September 2002. It was unsurprising that the Secretariat had expertise on the specific question of simplification, because amongst its members was Hervé Bribosia, whose previous work included acting as Rapporteur on the European University Institute's much quoted pre-Nice project on simplification of the treaties, which was sponsored by the European Commission: 
Secretariat contributed directly to innovation as well as to explaining the relevance of the EU's constitutional acquis to the Convention's own work. Interestingly, the method chosen by the Secretary General Sir John Kerr for the elaboration of these papers, which involved both small teams of drafters and roundrobin brainstorming sessions at which the entire Secretariat was able to make an input into papers, strengthened the cohesiveness of that organisation, which became more and more influential as the Convention drew to a close. Kerr's team-building skills surprised many people, who were not - in contrast - surprised by his quick mastery of the many complex substantive dossiers involved in the Convention project, even though he had not been directly involved in European affairs since 1995. ${ }^{41}$

Inevitably, of course, the Secretariat provided the background expertise for the preparation of crucial documents such as the mandates of the working groups and (in almost all cases) the working group draft reports, under the political control of the Praesidium and the Chairs of the respective working groups who were in turn drawn from the Praesidium. Florence DelocheGaudez cites its expertise as one of its key resources. ${ }^{42}$ Likewise, the Secretariat provided substantial input for crucial documents such as the October skeleton for a new Constitutional Treaty ${ }^{43}$ and the subsequent tranches of draft articles and successive redrafts. ${ }^{44}$ There can be little doubt that the Secretariat was crucial to the drafting of all key documents, with the exception of the draft Preamble which Giscard is thought to have worked on alone. Other documents, such as the initial skeleton published in October $2002,{ }^{45}$ were probably largely produced by Giscard and the Secretary General, working together. The lack of wider consultation might explain a curiosity such as the idea of dual citizenship (European/national) which was not a derivation from the existing treaties, which mysteriously appeared in the October 2002 draft, but which disappeared from a later February 2003 draft in favour of a return to a text which reproduced the existing EC/EU Treaties. ${ }^{46}$ What was clear was the Secretariat's role in preparing reports on reactions to the draft articles and beginning the task of collating the huge number of amendments proposed, especially to the initial foundational articles of the draft Treaty, a daunting exercise in the management of information.

The Secretariat was also responsible for preparing summaries of plenary meetings and working group meetings, although these were apparently

Robert Schuman Centre, 2000. For commentary, see K. Feus (ed), A Simplified Treaty for the European Union?, London.

41 Deloche-Gaudez, above n.25 at p.61 and p.63. After service as the UK's Permanent Representative in Brussels, up to 1995, he was subsequently UK Ambassador to the United States of America and then finally Permanent UnderSecretary of State at the Foreign and Commonwealth Office before taking retirement.

42 Deloche-Gaudez, above n.25 at pp.61-62.

43 See above n.29.

44 These documents are too many to list separately. For guidance on how the separate tranches of articles built up into the final conclusions of the Convention see <http://www.fedtrust.co.uk/constit_draftconsttreaty.htm>.

45 CONV 369/02, above n.29, Article 5.

46 CONV 528/03, 16 February 2003 (Articles 1-16), Article 7. 
drawn up under the sole authority of the Secretary General, rather than the Praesidium, as it was not felt desirable politically by the majority of the Praesidium to have such records. These latter summaries did not always receive unanimous support from 'embedded' Convention watchers as faithfully representing the debate. From time to time, the 'watchers' would have seen a particular point receiving very strong support from individual Convention members, where the meeting summary represented this as merely involving 'a number of Convention members'. However, there is nothing surprising in this, as the role of the minute taker in a meeting has since time immemorial offered the opportunity to control the agenda as well as to present the outcomes of deliberations in a particular light.

That comment leads directly to the final aspect of process which needs to be highlighted in this section of the paper, namely the management of the whole process of constitution-building. When the Member States agreed, in the Laeken Declaration, to the establishment of the Convention, one of the 'checks' which they placed upon its capacity to produce unintended, and perhaps unwanted, outcomes was the nomination of ex-French president Giscard d'Estaing to chair the Convention, bearing in mind that he was a man known to have a capacity for strong leadership, a reputation for independence, but perhaps most crucially a proven background of support for a view of European integration which preserved a strong role for the states. ${ }^{47}$ Doubtless many were surprised when Giscard so quickly seized the opportunity to make his distinctive mark by expressing his immediate preference for the option of producing a single report from the Convention, not a series of options, a report which would take the form of a Constitutional Treaty. Moreover, Giscard showed himself to be markedly undeterred by the complexity problem - namely that the choice for a Constitutional Treaty itself begged the question of 'fit' and coherence with what needs to be carried over from the old Treaties in terms of institutional provisions, legal bases, and policy frameworks, and what needs to be decided new from scratch. ${ }^{48}$ To that end, he instituted the group of legal experts from the European Union institutions, which was charged with leading the way towards the drafting of what eventually became Part III of the Constitutional Treaty. ${ }^{49}$ Indeed, one could surmise that the impact and effect of Giscard

47 See, for example, his advocacy of a cautious approach to enlargement, in the posteuro era: V. Giscard d'Estaing and H. Schmidt, 'Time to Slow Down and Consolidate Around "Euro-Europe", International Herald Tribune, 11 April 2000.

48 It could be argued, indeed, that Giscard kept the members of the Convention busy with the constitution-building aspects of its work in order to distract them from spending sixteen months discussing (falling out over?) the revisions to the institutional set-up inherited from the Treaty of Rome and tinkered with repeatedly in successive treaties, which were always going to be the most intractable problems facing the Convention and the ones least likely to be solved by the application of the deliberative aspects of the Convention-method. In fact, of course, there were many discussions of the institutional questions - but they were largely kept off the official agendas of the Working Groups, Discussion Circles and Plenary meetings. This was doubtless not an accident.

49 CONV 529/03 of 6 February 2003 Remit of the group of experts nominated by the Legal Services. The group's work very substantially influenced the provisions of Part III of the Treaty when it was first issued: CONV 725/03, 27 May 2003. 
within the Convention and its work could be said to be one of the unintended and unexpected consequences of the process, rather than one of the checking factors serving the interests of Member States, presumed at the outset to be unwilling to countenance too dramatic a shift from the status quo. At the same time, Giscard showed himself to be sensitive to the core concerns of the Member States, ensuring key national representation in the Secretariat (especially in the person of the British Secretary General, Sir John Kerr), and engaging in some controversial bilateral contacts with national capitals.

Giscard showed himself to be simultaneously both controlling and flexible in relation to the process of compiling the Treaty. ${ }^{50}$ A form of dirigisme was probably the leitmotiv of Giscard's overall orientation towards the Convention. Control stemmed above all from the insistence on issuing separate tranches of articles as these were approved by the Praesidium. This made it more difficult for those Convention members who were not on the Praesidium and who therefore had relatively little sense of the overall enterprise to address their comments to what they anticipated might be the final structure of the Constitutional Treaty, other than by relying on the original framework issued in October 2002. Furthermore, to the considerable disadvantage of national parliamentary members of the Convention who found it particularly difficult to fulfil their mandate to stay in touch with the views of their constituencies, very short deadlines were consistently given for submitting amendments and reactions to each fresh tranche of draft articles.

There is also evidence from plenary debates that Giscard did try to control some of the most influential voices on the Convention - that is, those who were on the Praesidium and who were therefore privy to the early drafts of Treaty articles and to the Praesidium's own discussions about the direction the new Constitutional Treaty should take - by using some form of collective 'cabinet responsibility' to muzzle those who had argued their case for a different view, but who had lost out, in the Praesidium's private meetings. Thus, at least up to the point when the Praesidium began to assert its independent authority in relation to the question of institutions, ${ }^{51}$ there was no substantial evidence of Praesidium debates being replayed in public in the plenary. Those who had lost the debate in the Praesidium found it harder although not impossible to bring the same arguments before the plenary. In fact, only the other two members of the three person Presidency, Vice Presidents Jean-Luc Dehaene and Guiliano Amato, along with Klaus Hänsch of the European Parliament, showed much inclination to stick very closely to collective 'cabinet responsibility'. On the hand, the Commission, with its numerically small representation (both full members are also members of the Praesidium), always found it a little difficult to be really effective in both Praesidium and Plenary, since its alternate members were not politicians of stature but rather senior officials.

Furthermore, control manifested itself in Giscard's own oral summaries of plenary debates at the conclusion of individual Convention sessions and in

50 For a sustained narrative of the Convention 'story', which builds in the key role of Giscard throughout the process, see generally Norman, above n.26.

51 See the original draft on institutions, Title IV of Part I, CONV 691/03, 23 April 2003. 
his presentations from time to time of the next steps which the Convention should take to advance its mandate, as well as in the way in which he acted politically outside the confines of the Convention, especially by engaging in a bilateral way with certain key Member States, thus sending out certain strong political messages about who matters and who does not.

As to flexibility, this was demonstrated by the willingness to countenance the creation of new sub-groups of Convention members to deal with problems and issues as they arose, whether the Working Group on Social Europe which was set up right at the end of the Working Group phase in response to a bottom-up movement of Convention members, or the discussion circles on specific matters such as the Court of Justice, ${ }^{52}$ budgetary matters and latterly the question of taxation. It was also evident from Giscard's responsiveness to changing political contexts, such as his willingness to 'pull' the periodic report which he had hitherto delivered to each European Council meeting, when faced with the risk of being almost completely squeezed out of the agenda at the Spring 2003 European Council in the wake of the UN Security Council debacle and the launch of the US/UK military action in Iraq. At the same time, this potential 'loss of face' was quickly counterbalanced by an attempt to persuade the Greek Presidency to implement a plan for the European Council to meet specifically to deal with Convention matters on 30 June 2003. Eventually that plan came to naught. However, Giscard sought successfully to place the Convention on the agenda of the European Council meeting in Athens in April 2003, which had been convened for the specific purpose of signing the Accession Treaties for the new Member States. This gave Giscard a visible and public role on this historic occasion.

What was particularly clear throughout the whole process was that there remained a signal lack of clarity about what the final product would look like. Literally hundreds of amendments were proposed by ordinary Convention members to each set of draft provisions put forward by the Praesidium, and only a proportion of these could be discussed at each plenary meeting. Thereafter, the Praesidium would 'think again', but the mass of Convention members were left largely in the dark as to what this might involve. Furthermore, the release of the draft provisions on the institutions was delayed to such an extent - they finally appeared to a great furore on 23 April 2003 - that it was hard to say how the whole product could be seen as positioned on the traditional intergovernmental/supranational continuum, which is so often measured in terms

52 The approach to the Court of Justice taken in the Convention could be - and doubtless will be - severely criticised for its failure to take seriously fundamental questions about judicial architecture and judicial resources. So far as the Court institutionally - would be affected by the changes proposed in the draft Constitution, this concerns largely mere tinkering at the margins. On the other hand, it is conceivable that the changes - if and when instrumentalised in a new Treaty entering into force upon ratification - could lead to additional demands upon the Court, especially in relation to fundamental rights, following the incorporation of the Charter of Fundamental Rights into the Constitution, as Part II. Speculation to that effect can be found in a rather sensationalised article in the Economist, 27 January 2004, entitled 'Government by Judges?'. It quotes Irish Court of Justice Fidelma Macken as saying it would be 'foolish' to assume that the Charter will have no impact on the Court's case law. 
of certain key questions about institutional powers and interinstitutional relationships. This tended to fuel the conspiracy theorists who suggested that the final proposed Constitutional Treaty would magically appear in large measure from Giscard's back pocket, or indeed from his top hat, in the manner of the magician's proverbial rabbit, although in the event that fear was largely unfounded. Alternatively, of course, a number suggested that the magic might be provided by Sir John Kerr, the Secretary General. However, a number of changes to the provisions introduced in the last hectic days and hours of the Convention did not appear to have come in any meaningful way out of the Convention's deliberations, such as the principle of 'citizens' initiatives', tacked onto what was finally agreed by the IGC as Article I47(4) CT. Article I-47 deals with the principle of participatory democracy.

Furthermore, some of those involved in the Convention regularly expressed displeasure at finding what they believed to be unwarranted departures in the articles issued by the Praesidium from what they perceived to be the 'results' of the Convention's work so far, embodied in its plenary discussions and its working group reports especially. ${ }^{53}$ But so much was said within the Convention, with so many different meanings and purposes, that gleaning a single consensus from these expressions of view was inevitably a judgemental exercise. To that extent, one person's consensus is another's dissensus, as the contested summaries of Convention meetings made clear. For the purposes of the argument in this paper what is most important is that lack of clarity about the overall output can lead to competing and contesting positions being advanced about the extent to which the final product will or will not be innovatory compared to the current state of European constitutional law. For example, Jean-Luc Dehaene, Vice-President of the Convention, called it 'evolution not revolution', ${ }^{54}$ stressing that there will be much that is familiar to cognoscenti of the existing Treaties in whatever is eventually proposed by the Convention. UK Government representative Peter Hain called it a 'tidying up' exercise. Usefully, for observers of the Convention, the reports on the separate tranches of articles and key Working Group Reports which were produced in quick succession in Spring 2003 by the UK House of Lords Select Committee on the European Union ${ }^{55}$ stressed in each case 'what was new' and 'what was old', and above all what was omitted in the new text from what was old. An example of this is the reference to 'ever closer union amongst the peoples of Europe' which was dropped from the Praesidium's draft of what were then Articles 1-16 of the draft Constitutional Treaty. ${ }^{56}$

53 E.g. P. Hain, 'The Future of Europe: A Union of Sovereign States', Speech, Adjournment Debate, Westminster Hall, London, 20 March 2003; see also the interventions by Alain Lamassoure and others at the discussion of the Report of Working Group on Complementary Competences at the plenary of 7-8 November $2002<$ http://european-convention.eu.int>.

54 J.L. Dehaene, 'Towards a Constitutional Treaty for the European Union', Speech to Kings College London, Centre for European Law, 11 February 2003, at p.6.

55 See the numerous reports available at <http://www.parliament.the-stationeryoffice.co.uk/pa/ld/ldeucom.htm>.

56 CONV 528/03, above n.46. The term 'ever closer union' originated in the Preamble to the EEC Treaty, and was taken up in Article 1 of the Treaty on European Union. The preamble to the Constitutional Treaty picks this phrase up in 
It is this focus on the new/old combination of constitutional acquis refracted into the new Constitutional Treaty via the prism of the Convention's deliberations, and the creation of the sense of an autonomous Convention acquis, which leads from the focus on the Convention as process into a reflection upon questions of constitutional substance. This combination of new and old reflected legal and political choices alike. The shift to a focus on substance is the last step in this paper's endeavour to provide a close description of how the Convention is simultaneously both rooted in the 'old' constitutional framework of the EU, as well as constantly toying with innovations and new ideas. This section will concentrate upon just a small number of substantive issues which taxed the Convention, namely the treatment of fundamental rights in the Constitutional Treaty, the issues of sovereignty and supremacy in relations between EU law and national law and between the EU and the Member States, and the questions of competence division and exercise.

\section{The Substantive Dimension of Convention-Watching: Working Towards a European Constitution?}

Rights; supremacy/sovereignty; competences. These are three key issues which underpin the most sensitive normative aspects of the draft Constitutional Treaty agreed upon by the Convention in June and July 2003. They are issues which go to the heart of the question: what is the European Union and what functions ought it to serve? Each is examined in turn, the point being less to critique the approach taken by the Convention itself, but rather to show how the Convention had to face up to the delicate task of blending innovation and acquis, especially in so far as it could not (or should not) ignore the considerable extent to which the EU as it stands, at least as a proto-constitutional order, is a judicial creation. They also go to the heart of the fear that a formal constitutional settlement risks disturbing the delicate balance which underpins the current constitutional framework. ${ }^{57}$ However, the blending of the past and the future is not an innovation of the Convention and the IGC in relation to treaty reform. Historically the use of so-called rendez-vous and passerelle clauses in successive treaty amendments has linked the past and the future. A rendez-vous clause is one which explicitly picks up on an area where reform is acknowledged to be incomplete. This was clearly the case in relation to the Treaty of Amsterdam and institutional reform aimed at enlargement. A rendez-vous clause calls for the reconvening of an IGC to carry on the work of reform, hoping that perhaps at a later stage political conditions will be more conducive to agreement. ${ }^{58}$ A passerelle clause, of which there are a number in the Constitutional Treaty, especially in relation to shifts from unanimity to qualified majority voting, allow in

some respects by referring the peoples of Europe being 'united ever more closely': CIG 87/04, above n. 3

57 See J.H.H. Weiler (2002), 'A Constitution for Europe? Some Hard Choices', Journal of Common Market Studies, 40/4, pp563-580; for a reply, reluctantly accepting the value of a formal written Constitution, see M.P. Maduro, 'Is There Europe for a Constitution?' in J.HH. Weiler, I. Begg and J. Peterson (eds.), Integration in an Expanding European Union: Reassessing the Fundamentals, 2003.

58 E.g. Protocol on Enlargement attached to the Treaty of Amsterdam. 
effect a lighter weight process for reforming the EU decision-making processes, by allowing the Council to decide, by unanimity, for example, to move to qualified majority voting. In practice, no passerelle clauses have ever been used, but they are important symbolic elements of the continuous process of treaty reform.

\section{a) Bill of Rights}

It is hard to imagine a modern liberal polity with constitutional pretensions without some form of (binding) bill of rights as a definitive statement of social and civic values (as opposed to ad hoc protection of fundamental rights via the more elastic concept of general principles of law which is the status quo under EU law at present). ${ }^{59}$ How should the Constitutional Treaty take up this challenge? In that context, what should be done with the preexisting but currently non-binding Charter of Fundamental Rights for the EU?

Given the United Kingdom's signal awkwardness in the context of the drafting of the Charter during the course of 2000, and its double insistence on both the inclusion of certain 'horizontal' clauses which would limit the scope and effect of the Charter if it were legally binding and the apparently unconditional rejection of the possibility of the Charter as drafted ever being adopted as a legally binding instrument, the position taken by the UK in the course of the deliberations of the Working Group on the legal status of the Charter was widely thought of as an important breakthrough. ${ }^{60}$ While insisting again on the further strengthening of the horizontal clauses, the UK representatives did not as such dissent from a 'consensus' view that the Charter ought to be incorporated as legally binding into the Constitutional Treaty, a view which was widely shared in plenary debates on this question. In the event, that was the approach adopted by the Convention, ${ }^{61}$ and likewise although the UK continued to formally reserve its position on this question until the very end, the IGC settled upon incorporating the Charter as Part II of the Constitutional Treaty. Far from settling all the relevant issues, however, the effect of this changed political determination on the part of a previously dissenting Member State was to open more questions than it answered, and indeed not all of the questions can be answered just by

59 This does not appear to be the view of the UK Government, as demonstrated by its response to the $6^{\text {th }}$ Report of the House of Lords Select Committee on the European Union, Session 2002-2003, which considered The Future Status of the EU Charter of Fundamental Rights. In response to the Committee's comment that 'any new constitution for the Union should be accompanied by a bill of rights', the Government responded that it 'does not accept that any new constitution has to have a bill of rights', preferring instead - it would appear - the 'respectable argument' that the status quo system of fundamental rights protection was sufficient (House of Lords Select Committee on the European Union, $27^{\text {th }}$ Report, Session 2002-2003). In the end, the UK did not or perhaps could not prevent the Charter being formally included in the draft Constitutional Treaty approved by the Convention, although that does not finally settle the question, given that the matter then went before the IGC.

60 Final Report of the Working Group, CONV 354/02, 22 October 2002.

${ }^{61}$ See CONV 726/03, 26 June 2003, Draft of Part II with comments. 
looking at the texts finally approved by the Convention in June 2003, and adopted in large measure in the same form by the IGC. ${ }^{62}$

A first line of enquiry concerned the nature of the invocation of the Charter as a legally binding part of the new constitutional framework. Was it best to incorporate the Charter 'by reference', while leaving it in a separate document indirectly given legal force? Or should it be incorporated as an integral and explicit part of the text of the Constitutional Treaty? Once the latter solution was adopted, a further question arose: where in the Constitutional Treaty did it belong? At the beginning, before the general principles of the Union itself are articulated? Somewhere in the middle of Part I of the Constitutional Treaty, which sets out the constitutional framework of the Union? In a separate Part II or Part III of the Treaty, where its separateness would not break up the flow of the rest of the constitutional text? Or in an Annex or Protocol to the Constitutional Treaty, where it risked looking somehow downgraded in relation to the rest of the constitutional documentation. One factor was very important to the location debate. While the Charter was drafted on an 'as if' presumption, which reflected an intention to draft a text which was capable of being given legal force without further alteration, it was also drafted on the assumption that it was a separate text to the Union treaties. Thus its final provisions or horizontal clauses not only contained the infamous attempts to ensure that the Charter could not be interpreted as extending the scope of Union competence and that its effects vis-à-vis the Member States would be limited (see especially Article 51 of the Charter as currently drafted ${ }^{63}$ ), but also provisions which protected the integrity of legal fundamental rights protection under national law, Union law and international law, for the benefit of individuals (see especially Article 53 of the Charter). Once the Convention resolved to incorporate the Charter as part of the Constitutional Treaty largely unamended, so that the problem of overlap would be bound to continue with the other provisions of the Constitutional Treaty, then it needed certainly to address the issues which framed the intentions of those who drafted the Charter of Rights before it decided upon the question of location.

However, even once it was resolved that the Charter should be formally incorporated as Part II of the Constitutional Treaty, there remained some key questions about the relationship between the Charter and other sources of fundamental rights. ${ }^{64}$ The distinctive character of the Union's hitherto judge-

62 See generally de G. de Búrca, 'Fundamental Rights and Citizenship', in B. de Witte, 2003, Ten Reflections on the Constitutional Treaty for Europe, 2003, pp1144; M. Brand (2003), 'Towards the Definitive Status of the Charter of Fundamental Rights of the European Union: Political Document or Legally Binding Text?' (2003) 4 German Law Journal 395 <www.germanlawjournal.com>; E. Vranes, 'The Final Clauses of the Charter of Fundamental Rights - Stumbling Blocks for the First and Second Convention', European Integration OnLine Papers, 2003-007 <http://eiop.or.at/eiop/texte/2003007a.htm>; Dutheil de la Rochère, above n.2.

63 OJ 2000 C364/1.

64 See generally, I. Pernice, 'Integrating the Charter of Fundamental Rights into the Constitution of the European Union: Practical and Theoretical Propositions', (2003) 10 Columbia Journal of European Law 5; I. Pernice and R. Kanitz, 
led system of enforcement of fundamental rights, which has been based on Article 220 EC ('the Court shall ensure that the law is observed') and Article 6(2) TEU has been its dynamic and fluid character. This case law involves the Court referring as necessary to a substantial variety of possible sources of 'Community fundamental rights', including national constitutional traditions and different international law instruments, including but not confined to the European Convention on Human Rights and Fundamental Freedoms ('ECHR'). The Court has frequently referred to other fundamental rights sources such as the International Covenant of Civil and Political Rights and the European Social Charter in its case law. That acquis is to be carried forward into the post-Constitution era, as the Charter will not become an exclusive source of the Union's fundamental rights, although the privileged position of the ECHR will continue for a number of reasons. First, the reference to the ECHR is preserved in what will be Article I-9(3) CT, which effectively transcribes the old Article 6(2) TEU into the Constitutional Treaty. In the longer term, the Court of Justice may have to consider any possible dissonances between the legal force of the Charter of Fundamental Rights and the continuing recognition of fundamental rights as general principles of law within the EU legal order (Article I-9(3) CT). Second, Article II-112(3) CT contains the unchanged text of Article 52(3) of the Charter and this requires the meaning and scope of Charter rights which correspond to rights guaranteed by the ECHR to be 'the same as those laid down by the' ECHR. Finally, considerable complexity regarding the legal structures of rights protection in the future, should the Union succeed in the project promised in Article I-9(2) CT that it 'shall seek' accession to the ECHR. This is a proposal long supported by the influential House of Lords Select Committee on the European Union, amongst other voices. ${ }^{65}$ Overall, Article I-9 CT could be said to convey an enthusiasm of purpose, aiming at the protection of fundamental rights, rather than an economy of expression.

Finally, there is the sticky question of the content of the Charter and its relationship to the rest of EU law. There are substantial areas of overlap between the Charter and other provisions of EU law that have been included in the Constitutional Treaty, whether in Part I on general principles and constitutional structure, or in Part III on policies. Adjustment of the two sets of provisions to each other could have assisted the project of ensuring harmony of interpretation, but fell foul, in essence, of the desire not to disturb the text of the Charter. ${ }^{66}$ Article II-112(2) CT, picking up verbatim Article 52(2) of the Charter, recognises the overlap issue, by requiring that rights recognised by the Charter which are based on EU law are exercised in accordance with the conditions of the EU treaties. This seems to suggest that two sets of provisions could co-exist comfortably. Even so, there is likely to be a substantial task for the Court of Justice to determine the scope and effects of rights provisions especially where there is overlap between the

'Fundamental Rights and Multilevel Constitutionalism in Europe', WHI Paper 7/04 <http://www.rewi.hu-berlin.de/WHI/english/>.

65 This was the view taken by the HL Selection Committee in its report on the Charter: EU Charter of Fundamental Rights, $8^{\text {th }}$ Report, 1999-2000, HL Paper 67. It repeats the view in a more recent report: The Future Status of the EU Charter of Fundamental Rights, $6^{\text {th }}$ Report, 2002-2003, HL Paper 48.

66 de Búrca, above n.62, at p.29 et seq. 
Charter and the other sections of the Constitutional Treaty. Its task here will be to create synergies between the wider and already embedded acquis which it has developed in concordance with the existing treaties, and the acquis of the Convention and the new constitutional settlement. In a trenchant critique of problems raised by the juxtaposition of the Charter and the rest of the Constitutional Treaty, Erich Vranes has argued that 'existing doubts are reinforced as to whether the much-discussed "Convention method" really allows an appropriate treatment of fundamental, albeit technically intricate problems.' As he remarked,

"it may be comparatively easy to formulate the substantive fundamental rights provisions of a fundamental rights catalogue, as these necessarily consist of "open", i.e. indeterminate legal notions which have to be concretized on a case by case basis in years of jurisprudence. However, it is arguably disproportionately more difficult to embed such a catalogue into the multilevel EU and national legal orders and their interlinked fundamental rights systems - the results of which are particularly disputed and which are also interlaced with other European and international human rights instruments - in a manner which does not only avoid new but satisfactorily resolves future legal problems ex ante." 67

\section{b) Sovereignty and Supremacy}

We turn now to the questions of sovereignty and supremacy. The EU is a post-national polity, suspended between national polities and international regimes. The challenges of ensuring legitimate and effective governance will necessarily give rise to some difficult questions about how to articulate both the longstanding (judicial) principle of the supremacy of the law of the EU and the gradual consequential transformation of the traditionally singular sovereignty of Westphalian states into the shared sovereignty of a multi-level governance structure. The question arose as to how each of these judicial principles should be reflected in the Constitutional Treaty. For the UK, it was logical to object to the expression used in Article 1 of the Praesidium's first draft of the Treaty to the effect that 'this Constitution establishes the Union' ${ }^{68}$ since the clear derivation from the international law nature of the Union is that the Member States establish the Union and that the powers of the Union flow from the Member States, so that the Constitutional Treaty has only a derived and not an original status. The language of the Praesidium's draft subtly crossed the bridge between regime and polity, and challenged concepts of Westphalian sovereignty. The explicit reference to the primacy of EU law in Article 9(1) of the Praesidium's first draft also riled the UK. However, the statement that 'the Constitution, and law adopted by the Union Institutions in exercising competences conferred on it by the Constitution, shall have primacy over the law of the Member States', as adopted in the final version of Article I-6 CT by the IGC, is - as many commented in the plenary debate on 5 March 2003 - quite unexceptionable in view of the position under EU law as it stands. Take the Court's statement in 1964, in Costa $\vee$ ENEL that,

67 Vranes, above n.62 at p.15.

68 CONV 528/03, above n.46. 
"The transfer by the States from their domestic legal systems to the Community legal system of the rights and obligations arising under the Treaty carries with it a permanent limitation of their sovereign rights, against which a subsequent unilateral act incompatible with the concept of the Community cannot prevail." ${ }^{\prime 69}$

Quite apart from what that statement asserts about the nature of what was then 'Community law', one of the most controversial statements concerned the so-called 'permanent' limitation of sovereign rights. We will return to this in a moment. Staying with the supremacy question, for the moment, it is still worth considering whether or not it is indeed quite unproblematic to insert a supremacy clause into the Constitutional Treaty, on the grounds of the fact that this is already a facet of the Union's constitutional order. ${ }^{70}$ What the insertion could signal would be an important step towards the merging of the 'judicial constitution' and the formal legal constitution being worked on by the Convention. It could be said that this is in the spirit of Article 6(2) TEU, referred to above, which codifies some aspects of the Court's case law on fundamental rights. Pursuing the analogy with Article 6(2) TEU and the utility or effectiveness of codification, however, it is equally clear that this simple provision does not refer in full to the complex case law in which, for example, the Court has addressed the question of the extent to which Member States are bound by the Union's fundamental rights guarantees when they are acting in some way in implementation of, or within the scope of, EU law. One thing is for sure, that case law does not speak with a single voice, and what is more, its interpretation is highly controversial amongst legal academics. It is interesting to note that partly to preserve the integrity of EU law as a system, the Council Legal Service was heavily involved during the negotiations of the Fundamental Rights Charter in 2000 in seeking to bridge the gap between the Court's case law and the text of the Charter itself, including its restrictive horizontal clauses. This was achieved through the drafting of the 'explanations' published alongside the Charter in October $2000 .^{71}$ These explanations referred to the Court's existing case law on the effects of the Union's fundamental rights vis-à-vis the Member States as a statement of the present law, and the importance of these explanations has been buttressed by an amendment to the Preamble to the Charter of Fundamental Rights as it has been incorporated in Part II of the draft Constitutional Treaty, to the effect that 'the Charter will be interpreted by the courts of the Union and the Member States with due regard to the explanations prepared at the instigation of the Praesidium of the Convention which drafted the Charter.'

69 Case 6/64 Costa v ENEL [1964] ECR 585 at p.594.

70 See the cautionary comments in M. Dougan, "Some Comments on the Praesidium's "Draft Treaty Establishing a Constitution for Europe", Federal Trust Online Constitutionalism Essay, 7/2003, at pp.5-6, <www.fedtrust.co.uk/ eu_constitution>.

71 Note from the Praesidium, Draft Charter of Fundamental Rights of the European Union, Text of the Explanations of the complete text of the Charter as set out in CHARTE 4487/00, CONVENT 50, CHARTE 4473/00, CONVENT 49, 11 October 2000, <http://www.europarl.eu.int/charter/convent49_en.htm>. 
What emerges from this saga about fundamental rights and the Court's case law so far as concerns the question of the 'codification' of the principle of supremacy is, of course, that codification or consolidation ${ }^{72}$ of the 'judicial constitution' will never be entirely unproblematic. Dougan's analysis makes clear that problems will arise in the case of supremacy, ${ }^{73}$ just as Vranes has done likewise in relation to fundamental rights. ${ }^{74}$

One area of debate is the precise meaning of the supremacy principle, whether as general principle of hierarchy or as specific conflicts-resolution tool. That point is not insuperable, if one accepts that any constitutional provision on supremacy would in turn require substantial judicial elaboration over a period of time, and into that elaboration would be built the different macro- and micro-level functions of the existing principle and associated legal doctrine, with the Court of Justice drawing upon the rich judicial acquis since Van Gend en $\operatorname{Loos}^{75}$ and Costa v ENEL and perhaps adapting it to the changed circumstances generated by the Convention and the IGC. Furthermore, the argument that to include the supremacy principle is to draw attention to a facet of EU law best left hidden and visible only to legal experts and other elites is constitutionally disreputable. On the other hand, there have been problems with the apparent generality of the principle as set out in the Constitutional Treaty, in so far as it does indeed purport to apply to the whole of the Union as a single legal edifice, including the old second and third pillars. Even if the Union becomes a single legal entity, the now 'subterranean pillars' 76 will continue to have legal and political effects, especially in terms of the differing types of competences given to the institutions and the varying effects of the instruments in relation to different areas of Union activity. A distinction will continue to be drawn between 'first pillar' matters, to which the principle of supremacy is currently limited, perhaps now joined by the third pillar, if the developing trend towards 'communitarisation' of all aspects of justice and home affairs policy continues, and the area of Common Foreign and Security Policy. A principle of supremacy drawn from the case law of the Court of Justice on the EC Treaty might be thought simply inappropriate to this latter field of Union activity. Above all, though, the inclusion of the supremacy principle - like the reference to the foundational nature of the Constitutional Treaty in the Praesidium's early but later superceded draft of Article 1 of Part I - draws attention to the possibility that the Union is bridging the gap between regime and polity. It does so despite the fact that the final version in Article I-6 CT does not refer to the supremacy of the EU constitution over the national constitutions. Even so, the formal assertion of supremacy in this way

72 Consolidation is the term used by the House of Lords Select Committee on the European Union in a report on Articles 1-16: The Future of Europe: Constitutional Treaty-Draft Articles 1-16, $9^{\text {th }}$ Report, 2002-2003, HL Paper 61, p.17.

73 See Dougan, above n.70.

74 Vranes, above n.62. For a more positive view on the 'fit' of international, supranational and national fundamental rights sources in a multilevel constitutional system, see Pernice and Kanitz, above n.64.

75 Case 26/62 Van Gend en Loos [1963] ECR 1.

76 The disappearance of the Maastricht pillars 'underground' is an expressive point made by Kalypso Nicolaïdes in a presentation to the Federal Trust/UACES Study Group on the Convention, 7 March 2003, European Parliament Offices, Queen Anne's Gate, London. 
heightens the tension between the EU legal order and the national legal orders by reinforcing the fact that in many respects, as things stand at present, the various systems make incommensurable claims, especially about so-called 'competence-competence' (the power to determine the legitimate scope of competence), and that serious conflicts are generally avoided by judicial interpretation of these incommensurable claims, not by the intractable pursuit of fundamentally incompatible principles such as the supremacy of EU law or the sovereignty of the Member States under international law. To assert as much in the Constitutional Treaty may be to scratch at the evident sensibilities of many national constitutional courts, many of which prefer to rationalise the supremacy of EU law by reference to their own constitutional systems rather than the logic supplied by the Court of Justice, not to mention public opinion in a number of Member States. Of course, that may be the intended or unintended effect, but there is no doubt that crossing that particular rubicon will still require something akin to a constitutional revolution in Europe and in the Member States.

It is worth dwelling for a moment upon the story of how the supremacy principle has been moved around Part I of the Constitutional Treaty in its various versions before the Convention and then the IGC. In Spring 2003 intermediate versions of Title I of Part I of the Constitutional Treaty put before the Praesidium but not published to the Plenary, the supremacy principle was not included in the section on competences, but was slated for inclusion as part of a provision which subsequently became Article I-5 in the final version as prepared by the Convention, on relations between the Member States and the Union. ${ }^{77}$ This contains the so-called loyalty principle, a version of what is presently set out in Article 10 of the EC Treaty, which is as far as the Treaty texts currently in force go towards formally recognising the supremacy of EU law. ${ }^{78}$ However, by the time a full draft of Part I went back to the Plenary at the end of May 2003, the supremacy principle was (back) in - appearing as Article I-10. ${ }^{79}$ The Praesidium 'explanations' were terse in the extreme on this question: 'The reference to the principle of primacy has been accepted, as it is a basic principle of the Union legal system which has to be laid down in the Constitution. ${ }^{80}$ After the end of the Convention, the provision moved once more. During the early part of the IGC, a group of legal experts chaired by Jean-Claude Piris, Director General of the Legal Service of the Council, moved the provision again, repositioning it back in the general foundational provisions of the Union, away from the competence provisions. ${ }^{81}$ This was done in truth without explanation in the interests of 'consistency'. There it stayed throughout the IGC, so that it now appears as Article I-6 CT.

Returning to the question of the 'permanent' effects of joining the EU, the reference to 'permanent limitation' in Costa v ENEL seemed to some to suggest that a Member State could not secede from the EC/EU - a point

77 See Praesidium document dated 19 May 2003.

78 J. Shaw, Law of the European Union, London, Palgrave, 2000, $3^{\text {rd }}$ ed, at p.297 et seq.

79 CONV 724/03, 26 May 2003, Draft Constitution Volume I, Revised Text of Part One.

80 CONV 724/03, above n.79 at p.64.

81 See IGC 50/03 and IGC 51/03 of 25 November 2003. 
flatly contradicted in 1981 when Greenland seceded (as part of the untangling of its relations with Denmark). One way in which the old will blend with the new in interesting ways in the 'new' Union concerns the inclusion of a secession or voluntary withdrawal clause. ${ }^{82}$ The approach taken in the Constitutional Treaty (Article I-60) seems to imply a slightly different emphasis to the position elaborated for Canada and the case of (potential) Quebec secession by the Canadian Supreme Court. ${ }^{83}$ The Court introduced a clear duty on the part of all concerned to negotiate in good faith should a majority of the people of Quebec decide that they wished to secede from the Canadian federation. Article I-60 of the Constitutional Treaty is premised on the 'decision to withdraw', which is a unilateral act taken in accordance with the constitutional requirements of each Member State. Thereafter, the assumption is withdrawal will indeed occur, with the Union negotiating and concluding an agreement for withdrawal based on guidelines drawn up by the European Council, and the seceding Member State is excluded from the discussions in the Council and the European Council on the withdrawal agreement. Withdrawal can also take effect automatically after notification of the decision to withdraw, notwithstanding the absence of an agreement, unless the European Council decides otherwise. The framework thus assumes an immediate reinstitution of the arm's length relationship between members and non-members, a point buttressed by the insistence in Article I-60(4) that a state having once withdrawn must apply to rejoin via the normal route laid down in Article I-58. There is to be no halfway house associate membership or automatic right to rejoin. This aspect of the provision is tougher in the final version than in the original draft. $^{84}$ Interestingly, in contrast to Canada, where much important constitutional doctrine, such as on the twin principles of constitutionalism and democracy, has been judicially elaborated in the context of the whole issue of Quebec's potential secession and ongoing 'difference' from the rest of Canada, there have been no judicial interventions thus far on this issue. ${ }^{85}$

\section{c) Competences}

Turning, finally, to the issue of competences, it is widely thought - wrongly, quite probably - that there has been an unstoppable 'competence creep' in which the EU and its institutions have gradually encroached upon the (protected, sovereign) spheres of the Member States. ${ }^{86}$ Even if the argument is largely wrongheaded, and is based on a perverted view of the politics of law-making in the EU context as a politics of winners and losers, ${ }^{87}$ one of the

82 CONV 648/03, 2 April 2003, Art. 46.

83 Reference by the Governor in Council, pursuant to s 53 of the Supreme Court Act, concerning the secession of Quebec from Canada [1998] 2 SCR 217.

${ }^{84}$ CONV 648/03, above n.82.

85 For argument about the potential applicability of this approach to constitutional flexibility in the EU, see J. Shaw, 'Relating Constitutionalism and flexibility in the EU', in G. de Búrca and J. Scott (eds), Constitutional Change in the EU: From Uniformity to Flexibility?, 2000.

86 See, in contrast, the much more sophisticated diagnosis of the 'problem' of the competence system offered in Section 1 of A. Vergés Bausili, 'Rethinking the methods of dividing and exercising powers in the EU: Reforming Subsidiarity, National Parliaments and Legitimacy', in Shaw et al, above n.21.

87 S. Weatherill, 'Competence', in de Witte above n.62, 45 at p.46. 
greatest challenges for the Convention concerned how it should react to the argument bearing in mind that the existing system governing competence attribution, exercise and control is hardly a paragon of clarity in the EU and could certainly benefit from an overhaul. Moreover, as Franz Mayer has made clear, the discussion of competences is itself a cypher for other questions about the nature of European integration. ${ }^{88}$ However, once the choice was made for some sort of systematisation of types of competence and areas of competence, there could be little assistance from the Court's case law. Notwithstanding its usage of the terms exclusive and shared competence in the external relations sphere, the way in which the Court has approached the question has simply not been rationalised in terms of types or categories of competence. On the contrary, it has used the principle of attribution, which has unsurprisingly been preserved in Article I-11(2). Attribution has been widely used by the Court as the basis for establishing and testing the limits of competence by examining the scope and context of each individual legal basis to ensure that measures adopted on that basis correspond not only to the specific terms of that legal basis, but also to the wider ethos of EU law. That was the clear implication of the Court's rather contested judgment in the Tobacco Advertising Directive Case ${ }^{89}$ in which it declared in quite trenchant terms the outer limits of the forms which the exercise of EU competence could legitimately take in respect of the regulation of cross-border advertising of tobacco products. This operates both in relation to the regulation of the internal market as a functional competence and also in relation to the question of the protection of public health as a substantive (complementary) competence. Indeed, in terms of the existence of competence, attribution is the only general principle that can be found in the Treaties as they are presently drafted, along with a vast number of legal bases, some of which are more carefully delineated than others, and of which Article 308 EC giving an implied power to regulate matters falling within the scope of the objectives of the Treaty is the most controversial. In addition, the Court has also evolved additional judicial principles such as the preemption of national legislative competence in certain circumstances and the doctrine of implied powers to buttress the attribution principle from the point of view of the efficacy of EU governance. Other principles, such as subsidiarity and proportionality, govern only the exercise of competence.

The original draft provisions on categories of competence prepared by the Praesidium were exceptionally inelegantly drafted..$^{90}$ Drafting style is a resolvable difficulty, and the final versions (Title III of Part I) were a considerable improvement, and also contain a more reasonable resolution of the division between exclusive and shared competence, especially in relation to the internal market. It remains a lingering difficulty, however, that the attempt to introduce a 'categories' approach drawn from the experience of other (national) federations does not appear to fit well with the existing approach to competences which constitutes the acquis communautaire in this

${ }^{88}$ F. Mayer, 'Competences - Reloaded? The vertical division of powers in the EU after the new European constitution', Paper presented at Altneuland: The Constitution of Europe in an American Perspective, NYU-Princeton University Conference, April 2004 <http://www.jeanmonnetprogram.org/>.

89 Case C-376/98 Germany v Council and Parliament [2000] ECR I-8419.

90 See CONV 528/03, above n.46. 
area. One can anticipate, therefore, that a move in this direction could precipitate considerable uncertainty as the institutions, and especially the Court, adjust to the new approach, assuming the Constitutional Treaty is adopted by the IGC and ratified at national level in due course.

In the meantime, the key questions about the scope and nature of competences are largely resolved not by Part I of the draft Constitutional Treaty, over which the Convention laboured so long and so hard, but rather by Part III, which in contrast received much less attention and is, of course, largely a codification and recapitulation of what is contained in the EC Treaty with regard to specific legal bases and powers, and so on. Furthermore, since these provisions do not provide answers to many of the previously uncertain and open questions - and indeed how could they? - it seems likely that the debate about competences will continue to rage in the EU context.

\section{CONCLUSIONS}

Many questions about the Convention, the Intergovernmental Conference and the Constitutional Treaty are left to one side by this paper. This is not a paper shaped by the normative elements of the so-called Laeken mandate from the Laeken Declaration, which indicated that the Convention should be concerned primarily with making the European Union's core framework more accessible and legible to citizens, as well as more effective, in particular in view of the substantial 2004 Enlargement. We are not concerned here with whether or not the Convention and its draft Constitutional Treaty constitute a European 'constitutional moment', ${ }^{91}$ or with the competing internal and external rationales for the construction of a formal constitutional edifice at this precise stage of the EU's historical development. ${ }^{92}$ Instead, it looks at the Convention's draft Constitutional Treaty as a constitution-building process rooted in a largely analytically based conception of the EU as an evolving non-state polity.

Moreover, this is not a paper trying to show what theory of integration applies best to the Convention, or a paper seeking to judge whether a 'Convention plus IGC' configuration is fundamentally different in terms of the amendment of the treaties to an 'old-style' IGC. In other words, it is not trying to figure out whether the Convention has produced different outcomes. In the main, the work in this paper is descriptive and analytical, trying to work out questions of fit between the old and the new.

Thus, this paper has offered a close examination of some key aspects of the emergent 'new' European Constitution, concentrating particularly upon the work of the Convention up to July 2003. The predominant focus is upon the questions of process and substance which shaped the work of the Convention

91 N. Walker, 'After the Constitutional Moment', in Pernice and Maduro, above n.2. See also N. Walker, 'Europe's Constitutional Momentum and the Question of Polity Legitimacy', <www.jeanmonnetprogram.org>; and N. Walker, 'The EU as a Constitutional Project', Federal Trust Online Constitutional Essay, 19/2004 <www.fedtrust.co.uk/eu_constitution>.

92 See G. de Búrca, 'The drafting of a Constitution for the European Union: Europe's Madisonian Moment or a Moment of Madness?', (2004) 61 Washington \& Lee Law Review 555. 
on the Future of the Union. The paper had a set of very modest objectives, namely to link debates about the Convention process to the substance of constitution-building and to show the influence of both the old Union acquis and the new mixed acquis of the Convention itself on the shaping of an anticipated new constitutional settlement for the EU. It has not been an attempt to provide an interim assessment of the results of the Convention, in terms of either process or substance. It is clear that in some cases the fit between the two is quite unsatisfactory, and this will generate legal and perhaps political uncertainty for a substantial period of time. Above all, in this context, simplification - that old mantra - can by no means be guaranteed. Throughout, the Convention's work has undoubtedly provoked quite strong reactions, ranging from fierce optimism to rather depressed pessimism, even amongst those who share the view that constitutionalism can and should, if pursued effectively as a set of premises about legitimate rule, offer some sort of legitimacy surplus to the presently much maligned EU. Balance is clearly a key issue: balancing the interests of the various constituencies with a stake in the Convention to ensure maximum acceptability of its final product; balancing growing scepticism amongst publics about political institutions with the evident sense of goodwill towards European institutions frequently charted in Euro-barometer polls which indicate that Europe ought to be given a decent chance to establish itself; finally, and perhaps most crucially, balancing the new and the old in the Constitutional Treaty, and re-engaging with one of the oldest conundrums of legitimacy, namely balancing the responsiveness of institutions including guarantees of participation, with the need for effective governance and leadership in an ever more uncertain world. 